Historic, archived document

Do not assume content reflects current scientific knowledge, policies, or practices. 

UNITED STATES DEPARTMENT OF AGRIGU TITERA BULLETIN No. 236. A E

Contribution from the Office of Markets and Rural Organizaino CHARLES J. BRAND, Chief

Washington, D. C.

$\nabla$

May 1, 1915

\section{A SYSTEM OF ACCOUNTS FOR}

\section{FARMERS' COOPERATIVE ELEVATORS}

By

JOHN R. HUMPHREY, Assistant in Cooperative Grain

Elevator Accounting, and W. H. KERR, Investigator in Market Business Practice

\section{CONTENTS}

Introduction Page

Types of Elevator Accounting Systems $\quad 2$

Office Equipment ........ 2

Taking an Inventory ....... 2

Auditing the Books

Hedging .......... 4

Insurance of Elevators . . . . . 4
Description of the Office of Markets and Rural Organization Grain Elevator Accounting System ....... . 4 Instructions for Operating the System - 8 Conclusion .......... 20

Blank Forms Nos. 1 to 15, Beginning at . 20

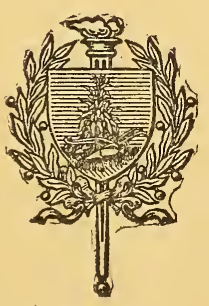

WASHINGTON 



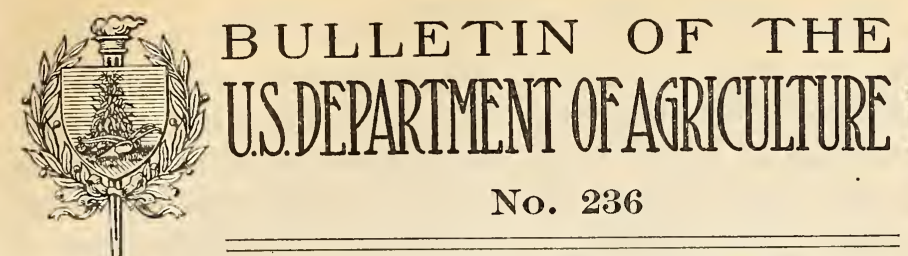

Contribution from the Office of Markets and Rural Organization,

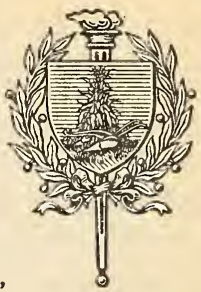

Charles J. Brand, Chief.

May 1, 1915.

\section{A SYSTEM OF ACCOUNTS FOR FARMERS' COOPERATIVE ELEVATORS.}

By John R. Humphrey, Assistant in Cooperative Grain Elevator Accounting, and W. H. KerR, Investigator in Market Business Practice.

CONTENTS.

Page.

Introduction. ...........................

Types of elevator accounting systems........

Office equipment........................

Taking an inventory

Auditing the books.......................

Hedging.

Insurance of elevators

1

2

2

2

3

4

4
Description of the Office of Markets and

Rural Organization grain elevator accounting system .......................... 4

Instructions for operating the system...... 8

Conclusion ............................ 20

Blank forms Nos. 1 to 15 , beginning at..... $\quad 20$

\section{INTRODUCTION.}

The rapid growth of the business of cooperative grain elevators has emphasized the importance of adequate accounting systems. It has been realized that the adoption of a uniform system sufficiently comprehensive to accommodate itself to the conditions prevailing in the grain-producing States would be a step in advance. This bulletin describes a grain elevator accounting system which has been devised by the Office of Markets and Rural Organization and which is now being used by representative elevators in seven of the leading grain-producing States.

In drawing up the various forms comprising this system reference has been made to many other systems now in operation. A firsthand study of conditions existing in the elevator business has likewise had a bearing on the final form of this system.

NoтE.-This bulletin is intended for all farmers' cooperative and other elevators throughout the United States. It contains copies of forms and a description of their uses for a system of accounts which is being recommended by the Office of Markets and Rural Organization, United States Department of Agriculture, as a uniform system for farmers' cooperative elevators. 


\section{TYPES OF ELEVATOR ACCOUNTING SYSTEMS.}

Investigations in respect to accounting in cooperative grain elevators have established the fact that no system has been generally accepted as standard. The idea of double-entry bookkeeping, while existing in a thorough sense in only a limited number of elevators, is followed more or less vaguely in all, and for that reason there is found every variation in type from patented systems to mere handbook entries kept in memorandum form for the benefit of the manager.

All the systems of bookkeeping now existing in elevators may be classified under three general headings: Complete double-entry systems kept in the elevator; incomplete systems, consisting of reports and memoranda kept in the elevator; and complete systems of reports made up at the elevator and sent to some outside agency where the records of the company are kept.

Of the three, the first should prove the most satisfactory for the reason that, although the third system may furnish definite information, the details of that information are not, as a rule, within easy reach of the men who are most interested in them.

The benefits to be derived from a complete double-entry system of bookkeeping, so constructed that it can be adopted by all elevators, are: First, the possibility of distributing and interchanging valuable statistics among elevators; second, the training of managers and bookkeepers, so that they will obtain a cumulative knowledge of elevator accounting, thus making it easier to procure competent help in these lines; third, the individual benefit derived by each elevator from knowing its financial and business condition with accuracy at short notice; and, fourth, the benefit to future buying in being able to ascertain the average net cost per bushel of operating an elevator.

\section{OFFICE EQUIPMENT.}

No system of accounts can be efficient unless it is properly handled. Office equipment is one of the important factors relating to the success of office work. An elevator office should be equipped with fireproof safes or a vault in which all valuable records of the company should be kept. It should have proper filing devices and sufficient furniture, including a standard bookkeeper's desk, to make thorough work possible. When the business of an elevator is large enough to justify the employment of a bookkeeper, such trained help should be secured, as, in most instances, the elevator manager is either without the knowledge or the time to perform the duties of a bookkeeper.

\section{TAKING AN INVENTORY.}

At the end of the business year or at the "cut off," an inventory should be taken. This should be an actual physical inventory, taken 
either by measurement of the grain in the bins or by running it out * of the bins and through a hopper or automatic scale, thus getting actual weights. The practice of taking estimated inventories by reference to the reports accumulated during the year's business is dangerous and, in most cases, absolutely inaccurate. The average platform scale has a weighing error of from 3 to 15 pounds per 60bushel load. This weighing error accumulating during a whole year sometimes amounts to a shortage or "overage" of hundreds of bushels. By taking inventories from grain reports, the elevator may, after five or six years, find itself with a book grain stock out of all proportion to the actual grain on hand at the time of inventory. By taking an actual inventory, the shrinkage or "overage" of each kind of grain is accounted for within the year to which it applies, and, if abnormal, can be checked up easily if an actual inventory has been taken the season before.

\section{AUDITING THE BOOKS.}

One of the features in elevator bookkeeping upon which great stress should be laid and to which an important position should be assigned is the auditing of the books as soon as the inventory has been taken. The custom prevailing among farmers' elevators of having internal audit committees furnished from the board of directors or the stockholders is commendable only to the extent of its usefulness in keeping the directorate in close touch with the business of the elevator. The positive value of such an audit, in so far as it is able to detect errors of principle or even clerical errors, is negligible, since, as a rule, the men making the audit are not especially trained for such work and use very little time to complete their reports. It should be apparent, then, that it is good business practice to secure the services of a certified public accountant who has had sufficient practice in elevator accounting to be able to give vital information and advice to the manager and directors of the elevator. Internal audit committees may work in conjunction with such an auditor, thus shortening the period of his labors as well as benefiting themselves by contact with him. The item of cost in connection with the hiring of public accountants has been the deterrent factor which, to a great extent, has kept the farmers' elevators in the past from availing themselves of such services. By banding together, several cooperative elevator companies might give an accountant steady employment throughout the year and secure his services at a greatly reduced rate. ${ }^{1}$

\footnotetext{
1 For further discussion of auditing, see U. S. Department of Agriculture Bulletin No. 178-Cooperative Organization Business Methods.
} 


\section{HEDGING.}

As a protection or insurance against loss from price fluctuations between the time of purchase and the time the grain is sold, an elevator may hedge its holdings. When grain is taken into the elevator it can be immediately protected by its sale for future delivery. When the grain is sold the hedge is taken up; that is, a purchase for future delivery is made. If the price of cash wheat has fallen in the meantime, the loss is counterbalanced by the profit on the hedge, as the future price will have decreased with the cash price. In this manner an elevator protects itself against loss by the drop in the price and waives the profit which might be made in case the price increased. Doing business in this way eliminates all chance of large losses or gains in the fluctuations in prices which take place from the time the farmer is paid for his deliveries until sales are made.

Dealing in futures should be allowed only where actual grain is hedged. Only lots of 5,000 bushels of wheat can be bought or sold for future delivery. Since an elevator often desires to protect smaller amounts, commission firms generally will accept orders for purchases or sales of futures in smaller quantities, say lots of 1,000 or 2,000 bushels. The commission firm then assembles its various orders and secures trades in lots of 5,000 bushels.

\section{INSURANCE OF ELEVATORS.}

The practice of insuring against fire is a well-established principle in respect to all property, but carelessness in keeping insurance which is sufficient to cover total loss has proven disastrous in many instances. Owing to the marked fluctuation in the amount of grain on hand during the shipping season, grain elevators particularly are likely to be underinsured. For convenience, it is advisable to insure buildings and contents under separate policies. The policy covering buildings seldom varies in amount during the year, but that covering: grain may be subject to change. Some managers in small towns, where no insurance agent is stationed, have protected their grain stock by insuring for maximum apacity. Others make arrangements with the agent allowing for changes on notice, and thus effect a saving in premiums paid.

\section{DESCRIPTION OF THE OFFICE OF MARKETS AND RURAL ORGANIZATION GRAIN ELEVATOR ACCOUNTING SYSTEM.}

As this bulletin is intended to be sufficiently complete to enable an elevator company to install the system as devised by the Office of Markets and Rural Organization, a detailed description of the forms comprising it is essential. 
The complete system includes 15 forms, as follows:

Form No. 1-Cash, journal, purchase and sales record.

Form No. 2-Record of grain receipts.

Form No. 3-Record of grain purchases

Form No. 4-Record of grain shipments and sales.

Form No. 5-Record of hedges.

Form No. 6-Record of sales to arrive.

Form No. 7-Patronage ledger.

Form No. 8-Grain and merchandise report.

Form No. 9-Manager's report.

Form No. 10-Grain check.

Form No. 11-Scale ticket.

Form No. 12-Storage ticket.

Form No. 13-Sales ticket.

Form No. 14-Cash receipt.

Form No. 15-Cost analysis.

For convenience of discussion, the description of the foregoing forms will be taken up in respect to the order of their use.

\section{SCALE TICKET.}

Form No. 11 (see p. 26) represents the scale ticket adopted under this system, but it is not essential that this exact form should be used, as any scale ticket which records gross, tare, and net, and gross dockage, and net of the load, together with designations as to the owner and kind of grain, will be satisfactory.

\section{STORAGE TICKET.}

In order that all grain may be accounted for properly upon receipt by the elevator, the adoption of the storage ticket as a means of recording bushels and pounds received is strongly recommended. Form No. 12 (see p. 27) represents such a ticket. Upon this ticket are recorded the gross dockage and net of all the loads which have been hauled in any one day by a single owner, as previously recorded on scale tickets. Storage tickets should be made up at the close of business each day. Both scale and storage tickets should be numbered consecutively and printed in duplicate.

For convenience in referring to the data entered on storage tickets it is advisable to file the tickets alphabetically under two headings, denoting "stored grain" and "purchased grain." By this system of filing, each patron's sales are kept together and settlement may be effected easily in the case of unsold grain through reference to this file. A small card file containing a card for each patron may be found of assistance in listing numbers of storage tickets and for furnishing other information for checking up the storage-ticket files.

RECORD OF GRAIN RECEIPTS.

After having registered all the receipts of grain on storage tickets under the names of their respective owners, entry should be made 
on the record of grain receipts (Form No. 2, facing p. 20), where the date, storage-ticket number, the kind, grade, and bushels of grain are noted.

\section{GRAIN CHECK.}

In buying the grain a special grain check should be used (Form No. 10; see p. 25), upon which are recorded, in addition to the information usually contained in a check, the number of bushels and kind of grain, together with the purchase price, minus any deductions for storage or accounts receivable, and the resultant amount of the check. Regular checks should be used for all expense and general items.

RECORD OF GRAIN PURCHASES.

These checks, being numbered consecutively, are entered according to number upon the record of grain purchases (Form No. 3, facing p. 20), where the net bushels, storage, and cost of grain are recorded in detail.

\section{RECORD OF GRAIN SHIPMENTS AND SALES.}

Shipments from the elevator are recorded upon the record of grain shipments and sales. (Form No. 4, facing p. 20.) Here the date of shipment, the party to whom the grain is consigned, the car number, and shipper's weight are recorded. As soon as the shipment has been sold and the returns have been received the date of sale, price received, destination, grade, and proceeds received for the grain are entered.

\section{RECORD OF HEDGES.}

A record of hedges (Form No. 5; see p. 21) is a form designed to record the transactions in futures bought and sold. The columns designated "Purchase and sales accounts" are used to record profits or losses on hedges, the "Remarks" column being used to designate the broker through whom the profit or loss is incurred.

\section{RECORD OF SALES TO ARRIVE.}

A considerable number of elevators selling grain "to arrive" have no form upon which the transactions can be recorded. Form No. 6 (see p. 21) represents a record of sales to arrive. A brief study of this form will be sufficient to demonstrate its usefulness. It has no part in the accounting system except as a memorandum of shipments made against contracts, but this is important in itself.

\section{MANAGER'S REPORT.}

Some elevators which are not doing sufficient business to warrant the hiring of a bookkeeper and in which the elevator manager is unable to keep the books have found it convenient to secure the services of a bookkeeper employed either in a bank or some store of the town in which they are located. For such elevators a manager's report 
(Form No. 9; see p. 24) has been provided. Upon this report the manager records all the transactions in receipts and purchases of grain and incloses duplicates of sales tickets covering sales of merchandise and of receipts for cash. From this form the bookkeeper, although not employed in the elevator, is able to keep the system of records in a satisfactory manner. The records of disbursements covering incidental items in most cases are controlled by the secretary or treasurer, and the bookkeeper should ook to him for records of this type.

\section{PATRONAGE LEDGER.}

In a few States cooperative laws have been enacted enabling cooperative organizations to distribute dividends upon a patronage basis, and for elevators operating under this law a patronage ledger has been devised (Form No. 7; see p. 22), upon which are recorded the individual purchases and sales of merchandise under the name of each customer.

\section{GRAIN AND MERCHANDISE REPORT.}

At the end of the year, just before balancing the books, an inventory of all merchandise on hand should be taken. Form No. 8, grain and merchandise report (see p. 23), has been provided with suitable headings so that the amounts of grain and merchandise on hand can be recorded. This form serves a valuable purpose in giving the value of net and stored grain on hand at date, from which comparisons can be made showing the amount of stored grain sold.

CASH, JOURNAL, PURCHASE, AND SALES RECORD.

Previously it has been usual to provide a cashbook, journal, and daybook under separate forms in elevator systems. In the system herein described these books, together with a record of purchases, have been incorporated into one form (Form No. 1, facing p.20), called the cash, journal, purchase, and sales record. As all the forms comprising this system, with the exception of reports and the patronage ledger, are in loose-leaf form, they may be contained in one binder (and the consolidation of four books under one form is a further condensation of the work). In the cash, journal, purchase, and sales record are recorded all regular cashbook entries, such as receipts of money and disbursements through checks, together with all journal entries and records of local sales of merchandise. Purchases of material such as flour, coal, etc., are recorded under "Purchases," giving pounds and amount.

SALES TICKET.

All the local sales of merchandise are originally entered upon the sales ticket (Form No. 13; see p. 28), and these sales tickets are made up in pads of 50 originals and duplicates, numbered consecutively. 


\section{CASH RECEIPT.}

All receipts of money other than checks are recorded upon a cash receipt (Form No. 14; see p. 29). It is quite essential that such a receipt be used, as the practice of receiving scrip or coin without making a record of the transaction at the time of receipt often leads to discrepancies which are difficult to account for later.

COST ANALYSIS.

A feature of this system and one upon which considerable emphasis should be laid is a cost analysis (Form No. 15; see p. 30), by which the relative amounts of grain handled and the actual and relative cost per bushel are determined. Upon this form a determination of the percentage of cost in handling merchandise is also worked out. The value of knowing the ratio of costs in the operation of a business is a well-established essential in many commercial enterprises, and it is no less important to the successful operation of grain elerators.

In conjunction with this system.any double-entry, loose-leaf ledger accommodating general accounts and accounts receirable may be used. To be assured of the correctness of entries, it is adrisable that a trial balance be taken from the ledger at the end of each month. ${ }^{1}$

\section{INSTRUCTIONS FOR OPERATING THE SYSTEM.}

\section{RECORD OF GRATN RECEIPTS.}

The record of grain receipts (Form No.2, facing p. 20) is a consecutive record of the receipts of grain as shown on the storage tickets. Having entered the storage tickets consecutirely for the period of a month, distributing the grain under the propel columns and recording it under gross dockage and net, in bushels and pounds, we may at the end of the month total this form to arrire at the total grain receipts for the period. The totals of the record of grain receipts are then carried to the grain report opposite the words "receipts this period." As the business progresses from month to month, each month's total should be kept separate; and, at the same time, a total should be drawn down, including the current month and the prerious months of the current year. This total is also carried to the grain report opposite the words "gross receipts." Under this system all grain is considered as theoretically stored regardless of whether it is purchased at the time of delivery or actually held in storage. This method is followed because it insures the proper accounting for every bushel of grain which comes into the elerator.

I See C. S. Department of Agriculture Bulletin No. 178, "Cooperatire Organization Business Methods," for further explanation of the value of trial balances. 
RECORD OF GRAIN PURCHASES.

The record of grain purchases (Form No. 3, facing p. 20) is a record of the net bushels and value of the grain purchased, together with storage which has accrued on the grain up to the time of purchase. Both the bushels and value of all grain recorded on this form should be totaled on dates to agree with the totals of the record of grain receipts. Like the record of grain receipts, the record of grain purchases should be totaled monthly. The totals showing the amount purchased for the year are carried to the grain report opposite "gross purchased." The total amount of all checks issued for grain in any month should be carried to the cash, journal, purchase, and sales record and there entered in the "bank withdrawal" column in one amount. The total cost of the various grains is then carried to the debit of the "grain accounts" in the "general ledger" column of the same form, this constituting a consolidated cash entry for all the transactions in grain purchases for the month. Where storage charges are represented, they should be credited to the "storage account" in the "general ledger" column, and in such cases the cost of grain should equal the amount of the check plus the storage charges, because the storage charges are deducted from the grain cost in order to arrive at the amount of the check.

\section{RECORD OF GRAIN SHIPMENTS AND SALES.}

The record of grain shipments and sales (Form No. 4, facing p. 20) carries a record of all cars shipped and the net returns from each shipment. The proceeds from each variety of grain should be totaled and posted at the end of the month to the credit of "grain accounts" in the general ledger. The items in the "net proceeds" column should be posted to the debit of the grain commission accounts represented in the "shipped to" column. The monthly totals of bushels from this form should be carried to the grain report opposite "shipments and sales this period." In the operation of this form it will be found that some of the shipments for any month will be still standing out as grain in transit at the end of the month. In beginning a new month, the 1st of April, for instance, it would be necessary to make an entry for the month of March as follows: "Total March returns on February shipments"; opposite this would be set down in total the net returns of all February shipments which had been received during March. In order to avoid confusion, however, reference should be made to February entries for posting to the individual "commission accounts." By this method the total returns on all grain will have been posted to the proper "commission accounts" by individual postings. Although we post only totals to the credit of the "grain accounts," the total receipts on each kind of grain shipped during the previous month $89896^{\circ}-$ Bull. $236-15--2$ 
and returned during the current month can be added in with the March shipments and returns in order to arrive at the total amount of returns for the month of March. This same method will apply if a car shipped in February should not bring returns until April, as the February entry would show that the car was still standing out through the month of March.

\section{RECORD OF HEDGES.}

A record of hedges (Form No. 5; see p. 21) is essential to the proper hedging of grain, and this account should be kept up to date. On this form columns hare been provided giving all the necessary information for keeping the accounting record of grain hedges. Profit or loss on hedges should be posted to the general ledger to the debit or credit of the "commission account" represented and to the debit or credit of "profit and loss on hedges," as the case may be. It may be considered that any profit or loss on hedging could as properly be charged or credited to the grain against which it applies, but, as it is important to know just how much the hedging of grain costs, it is much better to carry a "profit and loss on hedges". account until the end of the year, when this account may be written off to the sereral grain accounts if desired.

\section{RECORD OF SALES TO ARRIVE.}

Under the description of the system (p. 6) will be found sufficient information regarding this form (Form No. 6; see p. 21), for, as it is only an auxiliary record for memorandum use, it has very little to do with the operation of the system.

\section{PATRONAGE LEDGER.}

At convenient periods during the year reference should be made to the grain checks and to the sales tickets, and the amount of merchandise recorded thereon, both in purchases and sales, should be posted to the patronage ledger (Form No. 7; see p. 22), under the account of the customer with whom the transaction was held. It is essential only that this material be compiled by the end of the year, so that proper reference may be made to it as the basis for paying patronage dividends. Each customer's account is totaled and the rate of dividend per bushel or per pound is entered in the upper right-hand corner. Using this ledger as a basis, checks for the amount to which each customer is entitled can be made out, and dividends distributed accordingly.

GRAIN REPORT.

The grain report (Form No. S; see p. 23) is designed to keep the manager and directorate in close touch with the condition of their grain stock at the end of any month, or, in fact, at any time at which additions of the various entries on the grain forms may be made. 
Assuming that an elevator starts its current year with a certain balance of grain on hand, as shown by the inventory, at the end of the first month, by adding "receipts this period" to "balance last report," the result will be "gross on hand." By deducting from this the "shipments and sales this period," the difference will be the "net grain stock on hand." It is always important for a manager to know whether the grain which he has on hand belongs to the elevator in whole or in part, or is partly or entirely stored grain. By subtracting the gross amount of bushels of grain purchased from the gross receipts the total amount stored at date will be shown. Should this be greater than the net on hand, it will indicate that some grain which has been stored has been sold without being purchased from the owner of the grain-in other words, that there has been an amount of stored grain sold. Should the total stored at date be less than the net on hand, then the difference between the two would be the amount of purchased grain on hand.

\section{MERCHANDISE REPORT.}

The merchandise report (Form No. 8; see p. 23) serves merely as an inventory, giving the total on hand at the last inventory, purchases, sales, and net on hand, which should agree, allowing for proper deductions or additions, with the actual inventory.

\section{CASH, Journal, PURCHASE, AND SALES RECORD.}

The cash, journal, purchase, and sales record (Form No. 1, facing p. 20) differs from ordinary books of first entry in that both the debit and credit entries, which are to be posted later to the ledger, are of necessity entered on this form before it can be balanced.

The debit columns of this form are designated as follows:

Date.

Folio.

Cash.

Bank deposits.

General ledger.

Accounts receivable ledger.

Hard coal (lbs. ...., amount ....).

Soft coal (lbs. ....., amount ....).

There are also provided four columns in blank which may be used to suit the convenience and requirements of the individual elevator.

The credit columns comprise the following:

Check number.

Folio.

Bank withdrawals.

General ledger.

Accounts receivable ledger.

Sales ticket number.

Hard coal (lbs. ...., amount ....).

Soft coal (lbs. ....., amount ....).

Miscellaneous grain (lbs. ...., amount ....). 
There are also blank columns to be used as desired.

A column is provided between the debit and credit sides, marked "Items," in which are written all items and an explanation of them.

Debit Columans.

CASH.

In order that an accurate check may be had upon the amount of money received so that an identical amount may be deposited each day, all cash receipts of whatever nature should be entered in the "cash" column. These entries are footed daily and represent the amount of the deposit and are not carried forward during the month, all deposits being set down in the "bank deposits" column as the deposit is made.

BANK DEPOSITS.

In some instances where drafts are drawn directly against commission companies by the bank the money is not received at the elevator, and in such cases the deposit of drafts may be made directly into the "bank deposits" column. In this way the "bank deposits" column would include the total receipts at the elevator plus all receipts of drafts at the bank, and the total of this column carried forward during the month should equal the sum of the deposits in the bank pass book.

GENERAL LEDGER.

The "general ledger" column is provided for entry of all items to accounts in the general ledger for which no special columns are provided, and postings should be made in detail from this column to accounts in the general ledger.

ACCOUNTS RECEIVABLE LEDGER.

The accounts receivable ledger carries items for all local accounts receivable, and items in this column are posted in detail to accounts in the accounts receivable ledger.

PURCHASES.

Under the heading "Purchases" will be found columns designated "hard coal," "soft coal," etc., in pounds and amounts. All purchases of merchandise of this character are entered in their proper columns under this heading, and the totals only are posted at the end of the month to their respective accounts in the general ledger.

CREDIT COLUMNS.

The "check number" column accommodates the numbers of all checks drawn for expense and general accounts other than grain checks. The "bank withdrawals" column records the amounts of these checks. In this column is also entered the total of the grain 
checks drawn during the month. The "general ledger" and "accounts receivable" columns serve the same purposes on the credit as were explained on the debit side.

LOCAL SALES.

As all the sales tickets are numbered consecutively, their numbers are listed in the "sales number" column, and the merchandise in pounds and amount is entered in the proper column to the credit of the account to which it belongs, such as "hard coal," "soft coal," "flour," etc. These columns are totaled at the end of the month and the totals only are posted to the accounts in the general ledger. Only the items which are posted from the general ledger, accounts receivable ledger, and the miscellaneous columns are listed in detail, all other columns, both debit and credit, being posted as totals. At the beginning of the month the first entry to be made on this form is "cash balance," and this should be set down in the "bank deposit". column as an amount carried forward. Because of the fact that every debit has a corresponding credit, the two sides of this form should always be in balance, but the fact that we have carried forward the cash balance, which appears on one side only, must be taken into consideration. In order that the form should foot and prove correctly, it should always be out of balance by the exact amount of the cash entry at the beginning of the month.

THE LEDGER.

The ledger should be divided into two general divisions-one carrying general accounts and the other accounts receivable-and may be designated under the headings "General ledger" and "Accounts receivable ledger." In the general ledger will be found such accounts as: (1) Cash, which is the monthly balance as shown by the cashbook; (2) "accounts receivable control" account, to which are posted debit and credit totals in the "accounts receivable" columns in the cash, journal, purchase, and sales record, the individual items having been posted previously to the accounts receivable ledger. This account serves as a proof of the correctness of such individual postings. (3) Bills receivable, including all promissory notes, time notes, bills of exchange, or acceptances receivable.

It has been the practice in some elevator accounting systems to show a subdivision of expense in the journal, but the small number of items of this character is much better taken care of through a subdivision of the ledger accounts. An ordinary ledger page may be ruled by the bookkeeper into seven or eight columns, and, as entries to expense in most cases are debit items, no credit columns need be provided. When credits occur they should be posted in red 
ink and deducted in the addition of the items in the column. The several columns of the expense account may be headed "Salaries;" "Telephone, telegraph, and electric light;" "Taxes;" "Gasoline;" "Repairs;" and "Miscellaneous," or similar headings suitable to the nature of the expenses incurred.

An account should be provided showing the capital stock outstanding or the portion of the net capital which is used or is available for the working of the business.

Separate accounts should be opened for each kind of grain handled, showing the amount and value of grain purchased on the debit, and the amount and value of grain sold on the credit. At the end of the year, by crediting these accounts with the inventory of the kind of grain specified, the net profit on each kind of grain may be determined. In the case of local sales of grain, it is advisable to open separate accounts so that a clear record may be kept of the amount of grain sold locally, as well as in car lots. These local sales accounts should be closed into the general grain accounts at the end of the year.

During the course of a shipping season a considerable number of claims will arise against railroads for losses of grain in transit. Two accounts should be opened to accommodate this condition: A debit account-claims against railroads for leakage in transit, and a credit account-loss and recovery on grain leakage in transit. These accounts operate after the following manner: When a car is reported short a certain number of bushels under that recorded by the elevator's automatic scale, a charge is put through against the railroad responsible in the first-named account, and a corresponding credit is carried to the latter account. When recovery is received by remittance from the railroad company, the company is credited with the amount of the check. If the check does not cover the full amount of the claim, and no further action is to be taken looking toward its collection, then a journal entry for the remainder should be passed, crediting the account of the railroad in the claims account and debiting loss and recovery on grain leakage in transit. This latter account constitutes an income account and may be written off direct to profit and loss; or if the composition of the account is known, the specific items applying to certain kinds of grain may be credited to the grain accounts.

The following entries in the cash, journal, purchase, and sales record will serve to illustrate the method of accounting for loss and recovery on grain leakage in transit. When the grain is reported lost, the first entry to be made is as follows:

Debit Claims (B. \& M. Railroad) ........................... 25.00

Credit Loss and recovery on grain leakage in transit ............... 25. 00

After negotiations with the railroad, assume that settlement by an allowance of $\$ 15.00$ is received by check. Entry would then be 
made of the check showing "Cash debit \$15.00," and "B. \& M. Railroad credit $\$ 15.00$." This leaves a credit of $\$ 25$ to the account for loss and recovery on grain leakage in transit, and a debit to the railroad of $\$ 10$.

Considering that the transaction has been definitely settled, and that no further recovery can be made, the following journal entry should be passed:

Debit Loss and recovery on grain leakage in transit.......... 10.00

Credit Claims B. \& M. Railroad . . . . . . . . . . . . . . . . . . . . . 10.00

This simply closes the railroad account, and leaves a balance in the loss and recovery on grain leakage in transit representing the true amount of recovery.

THE COST ANALYSIS.

The cost analysis (Form No. 15; see p. 30) has been provided to furnish information affecting the unit and relative cost of handling grain and merchandise. The method of operation is as follows:

Opposite "Bushels of grain handled" should be set down, first, the total of all grain taken into the elevator, this amount being extended under the different kinds of grain as shown by the footings of the record of grain receipts, the total grain taken in being 100 per cent. The relative percentage of each kind of grain is then set down opposite the per cent mark under the column designated. On the same line should be added the value of coal and merchandise sales.

After taking out an amount which would seem to be sufficient for the selling of merchandise, the different kinds of expense applying generally to all kinds of grain and merchandise, such as salary, insurance, interest, power, and repairs, are then prorated according to the grain percentages. This amount will be, necessarily, more or less of an estimate, but a manager, by keeping account of the time spent on coal and merchandise sales in the space of a month, can arrive at a fair basis for the division of salaries. Insurance, interest, repairs, and miscellaneous, relating to merchandise, are contained in a few items and can be easily ascertained.

Such items as "Power operating" apply only to grain. "Corn shelling-direct labor" includes only that labor which has been procured especially for corn shelling, and would not include the manager's or assistant manager's time, as their wages are prorated under "Salaries." Car cooperage should be distributed according to the amounts of grain received, except in cases where an account has been kept in the ledger showing the exact amount of cooperage against each kind of grain.

After having prorated the different expense items, the addition of these gives the gross expense. Returns from storage and returns from dockage sold are then set down under the kinds of grain which have furnished these returns, and subtracted. Any returns from 
cobs sold are subtracted from cob corn. The net expense is then ascertained from these subtractions.

The total net expense being 100 per cent, the percentage of net expense of each kind of grain and merchandise will be determined as being the relative percentage of each to the total. The net unit cost of operation is determined by dividing the amount of expense by the number of bushels handled. The net unit cost in this operation would be in terms of cents or decimals of a cent. In the case of sales of coal and other merchandise the net unit cost of operation is represented by a certain percentage, as, for instance, 5 per cent of the gross sales, this percentage being determined by dividing the net expense by the value of goods sold.

\section{BALANCING CASH WITH THE BANK.}

To determine the correctness of the cash transactions for the month the following method will be found simple and adequate:

(1) Determine whether the "bank deposit" column agrees with the bank pass book as to individual deposits. Be sure that it is correctly footed.

(2) Sort the returned vouchers, arranging them consecutively. Compare them with the entries in the "bank withdrawals" column and ascertain which, if any, are missing. List the numbers and amounts of all outstanding checks for the next month's reference. Outstanding checks may be listed either on an adding-machine tape or by writing them into the cashbook. The difference between the "bank deposits" and "bank withdrawals" columns, plus the total of outstanding checks, should equal the balance as shown in the bank pass book. No error, however small, should be ignored in balancing cash with the bank.

\section{RESERVE ACCOUNTS.}

RESERVE FOR DEPRECIATION ACCOUNT.

In order to show the true condition of the plant a reserre for depreciation account is essential. To this account should be credited annually a certain percentage of the money invested in the plant, and an equal amount should be written off profit and loss. ${ }^{1}$

\section{RESERVE FOR BAD DEBTS ACCOUNT.}

During the operation of a business where credit is giren to a large number of customers there is likely to be a loss on account of uncollectible debts. This amount may be small one year and large another. For that reason it is well to set aside a sufficient amount of capital from the yearly profits to offset such losses. To effect this, "reserve for bad debts" should be credited and "profit and loss" debited with

1 For further explanation of reserve for depreciation see U. S. Department of Agriculture Bulletin No. 178, "Cooperative Organization Business Methods." 
an amount which experience would dictate is sufficient to take care of the uncollectible debts of the company.

While many elevator companies make a practice of furnishing supplies to members and others on credit, all supplies, if possible, should be handled on a strictly cash basis. Any system of extending unprotected credit requires a large capital and often results in considerable loss.

\section{RESERVE FOR SINKING FUND.}

In some States, notably South Dakota, where the cooperative law is in operation, a statutory regulation requires that a certain percentage of the capital invested be set aside each year in a reserve for sinking fund, so that the company will be in a position to retire its capital stock at the end of a given period. Companies operating under such conditions should set up a reserve for sinking fund in accordance with the requirements of their State laws.

Where the custom of hedging grain prevails, an account should be opened designated "profit and loss on hedging." To this should be debited or credited the losses or gains incident to the hedging of grain, the opposite entry being made to the commission account handling the business.

To determine the profit and loss for the year, all income accounts should be credited and all expense accounts debited to this account. When the amount of profit has been ascertained, dividends may be declared and paid, and the remainder transferred to the surplus account.

After the books have been closed for the year, any errors discovered affecting the previous year's business should be entered in the account affected and carried to the opposite side of the surplus account, the profit and loss account being reserved for the current year's business.

The individual needs and the peculiar conditions surrounding elevators in different parts of the United States may require other accounts besides those discussed above, and if such is the case, accounts covering these special requirements may be opened along the same general lines as those previously discussed.

The following balance sheet is submitted as a guide in the arrangement of assets and liabilities. Other asset and liability accounts may appear on the books of an elevator and in such case should be included. 


\section{STATEMENT.}

Farmers' Elevator Balance Sheet, Year Ending ASSETS.

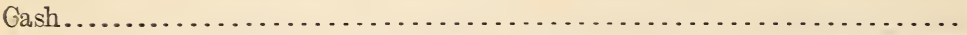

Accounts receivable.......................... $\$ 3,208.00$

$\$ 287.50$

L'ess reserve for bad debts..................... $\quad 400.00$

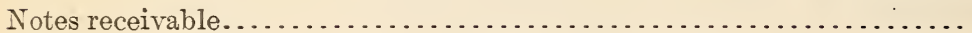

Plant and real estate............................ 9,500.00

Less reserve for depreciation. . . . . . . . . . $\ldots \ldots \ldots . \quad 300.00$

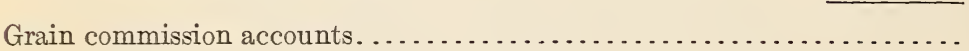
Inventory:

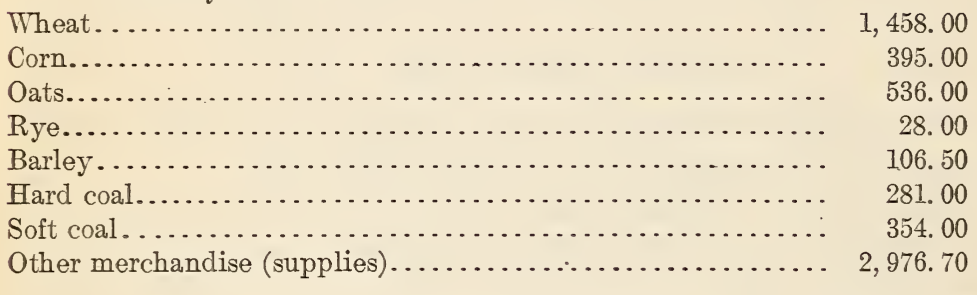

LIABILITIES.

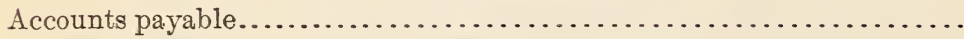

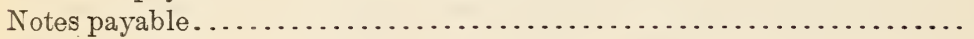

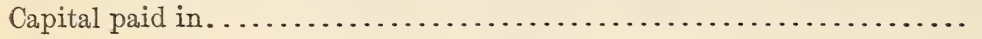

Surplus.

\section{SUPPLY ACCOUNTS SETTLED WITH GRAIN.}

When requests are received from patrons to deduct from the amount due for grain sold the amount which they may owe the company for supplies purchased, two grain checks should be issued. The first check should contain the total number of bushels and kind of grain being purchased, together with the balance due the patron after deducting the amount of his account from the full value of the grain.

A second check should then be made without reference to bushels of grain, and marked "For a/c receivable," in the full amount deducted from the previous check. This check is then indorsed over to the elevator by the patron and both checks are entered in the record of grain purchases, the first check going to the patron and the second being deposited to the account of the elevator as cash received. By this means both sides of the transaction have been carried out through the only proper medium of settling accounts, which is cash. 


\section{FILING STORAGE AND SALES TICKETS.}

Another method of compiling records as a basis for the distribution of patronage dividends, which is in operation in some of the elevators where the Office of Markets and Rural Organization has installed its system of elevator accounting, may be recommended for its convenience.

Under this method suitable drawers are divided into two compartments each by transverse partitions. Each front compartment should be of about one-fourth the size of the drawer. The back compartment is then fitted with an A-B-C index conforming in height with the material to be indexed. Two drawers of this description or a drawer divided into four compartments on the same basis will be necessary.

In one drawer are filed the storage tickets and in the other the sales tickets. In some States, where no grain is taken in storage, grainpurchase tickets are issued by the elevators, which bear, in addition to the usual information contained on a storage ticket, the items of price and value of grain. These purchase tickets are contracts to buy at a certain price, but for the purposes of this compilation of information they may be considered technically as storage tickets. The general term "storage ticket" will therefore be used in the discussions of both of these forms. All storage and sales tickets not paid for are filed consecutively according to number in the front compartment of the drawer designated for each. This should be done daily.

As checks are issued for grain and payments received against sales the tickets of each kind covered by these cash transactions are taken from the numerical file and then are placed in the A-B-C file under the name appearing at the top of the ticket.

It often happens that a storage ticket is issued under the name of one owner when in reality it is subject to joint ownership, and this fact would seem to make proper filing difficult: Before purchase by the elevator, however, the true condition of ownership appears.

As each owner is paid for his share, a slip bearing the original ticket number and giving the name of the owner, the bushels, and the kind of grain is filed under the proper letter. A notation is made on the original ticket of this deduction, and when the last owner to settle appears the original is filed under his name. Up to the point of final settlement the original ticket is held in the numerical file.

At the end of the year the A-B-C file will contain all the completed transactions grouped according to patrons' names. By use of an adding machine a complete list of the data upon which dividends are to be paid can be compiled in a few hours.

Using this method of filing as a basis the tickets may be entered individually in the patronage ledger or, where conditions permit, the 
adding-machine totals (which should first be verified) may constitute the only entry in the patronage ledger, thus saving a considerable amount of clerical labor without detracting from the accuracy of results.

For the convenience of those interested in the system described in this bulletin and for those who desire to have the system printed, the Office of Markets and Rural Organization has provided printer's copy of the several forms for free distribution.

All elevators installing the system of accounts may refer to this office any questions regarding its installation or operation.

A sectional post transfer binder has been found convenient and adequate for binding the accounting forms. The standard size is, length over all, $15 \frac{1}{2}$ inches, width $10 \frac{1}{2}$ inches, posts five-sixteenth inch in diameter and 7 inches from center to center.

\section{CONCLUSION.}

The foregoing pages outline very briefly certain information regarding operating grain elevators, and in particular describe the methods used in operating a system of grain elevator accounting. But the simple keeping of the records is not sufficient. To obtain benefits commensurate with the opportunities open in the field of cooperative grain elevators, the manager and directors of the elevators possessing such an accounting system should make use of all the information which it is able to furnish. If there is a common knowledge among the stockholders that the business of the elevator is being handled in a competent manner, and that details and statistics regarding it can be furnished at any time, it will act as a bond of faith and will secure the loyalty of the members to their organization. 


CASH, JOURNAL, PURCHASE, AND SALES RECORD.

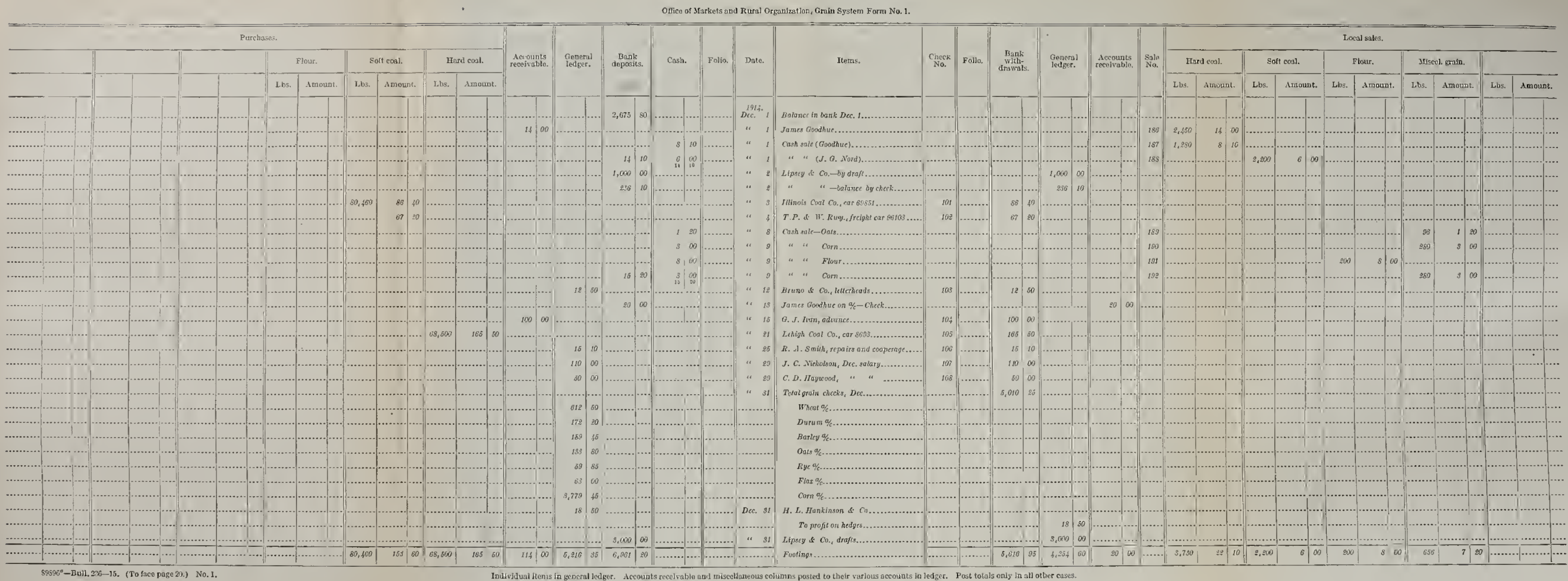



2.

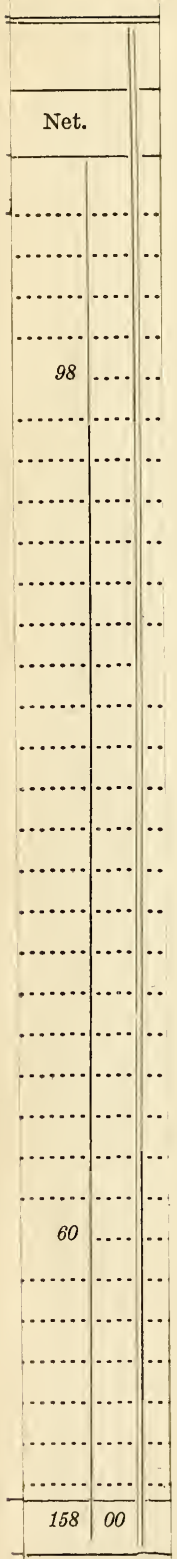

essary. 

RECORD OF GRAIN RECEIPTS.

Otibeo of Markiots and Rural Organlezstion, Orain System Form No. 2

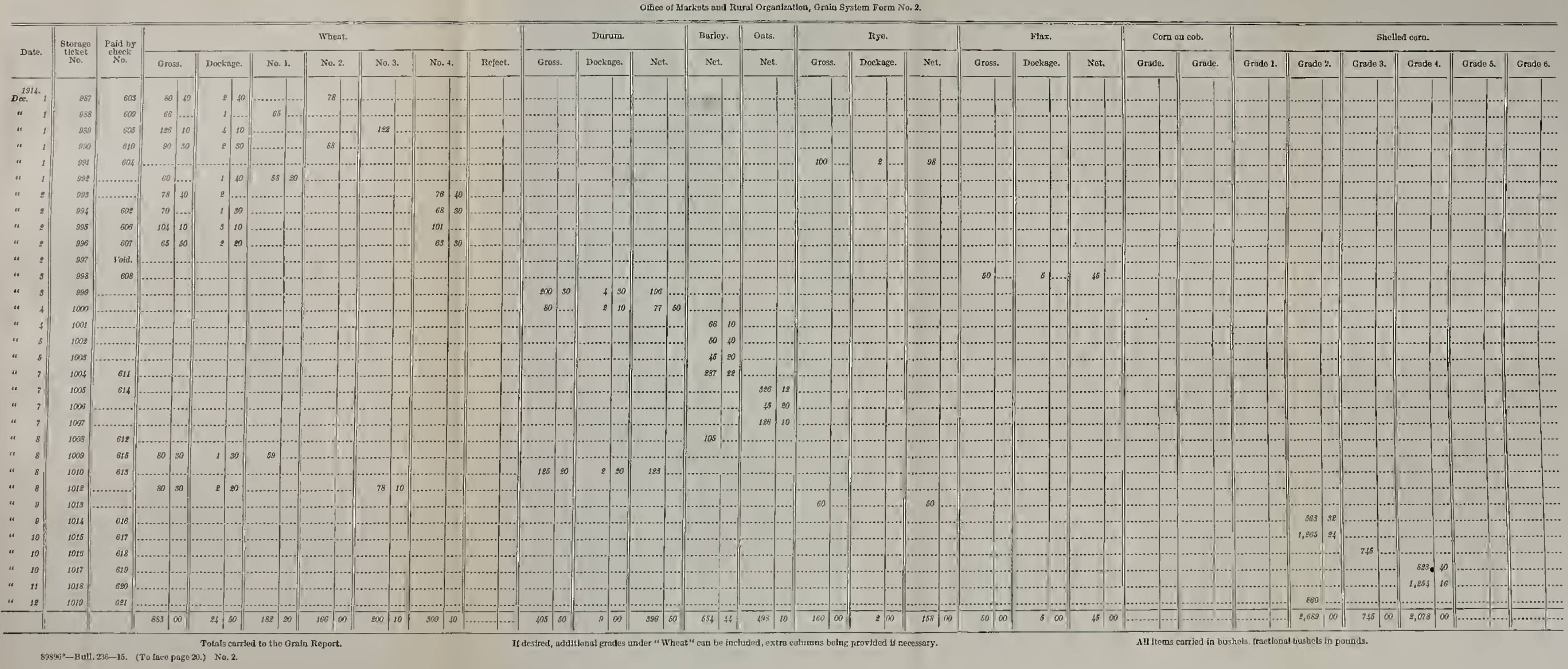



Off

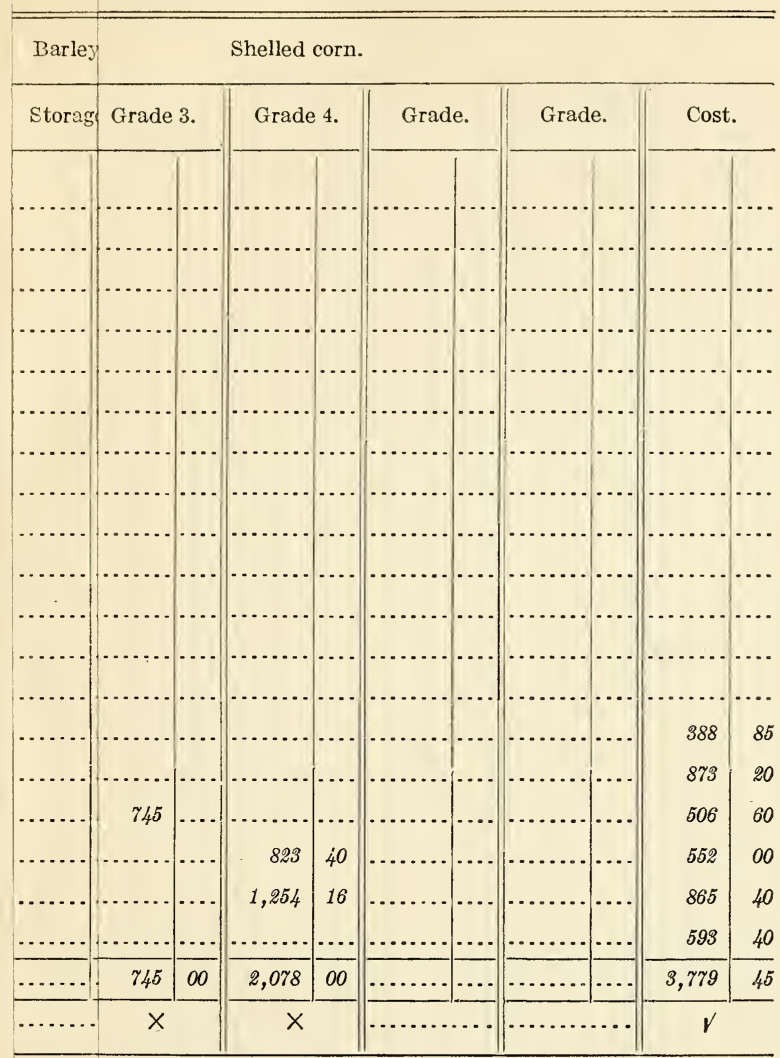

$\mathrm{s}$ in pounds.

RI

Office

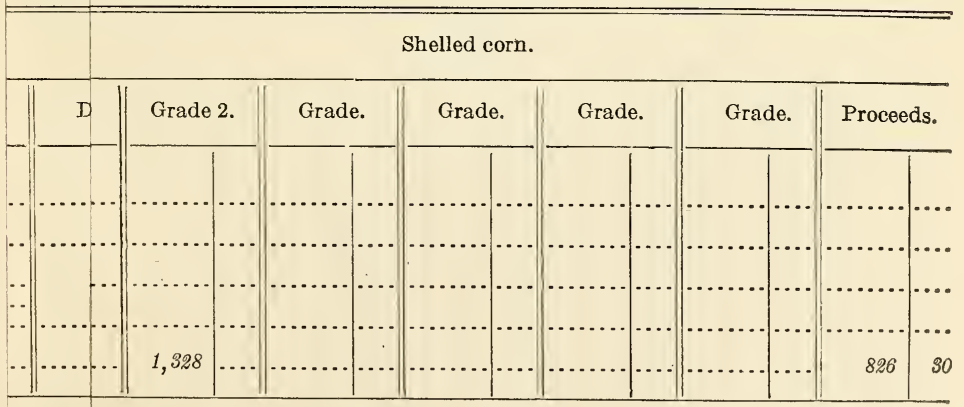

; to be $\mathrm{m}$ 



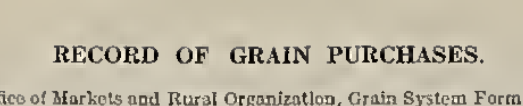

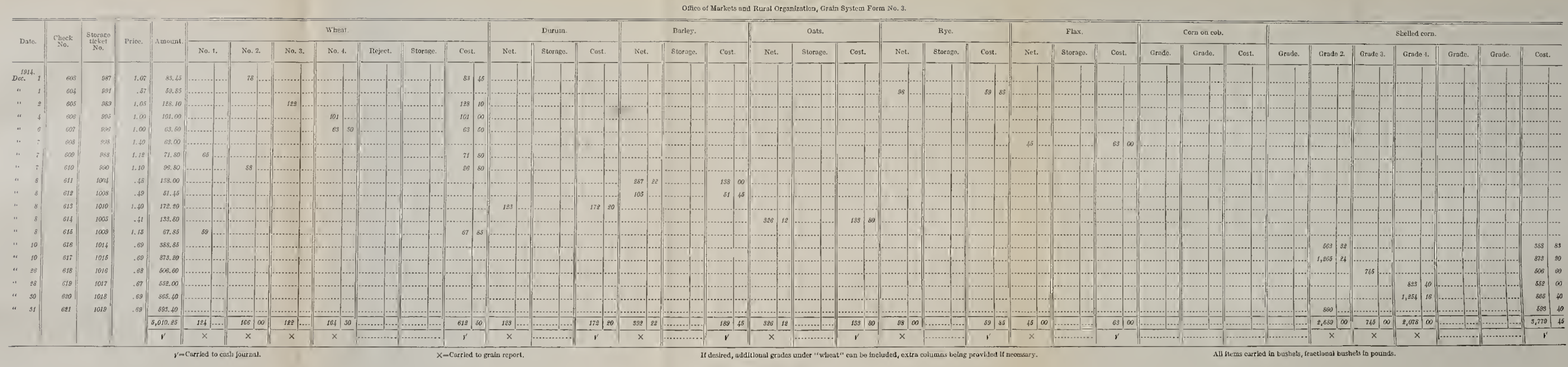

RECORD OF GRAIN SHIPMENTS AND SALES.

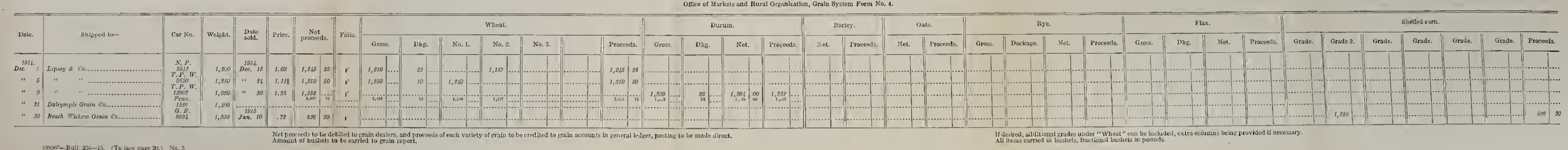



SYST'M O'F ACCOUNTS FOR FARMERS' COOPERATIVE ELEVATORS. 21

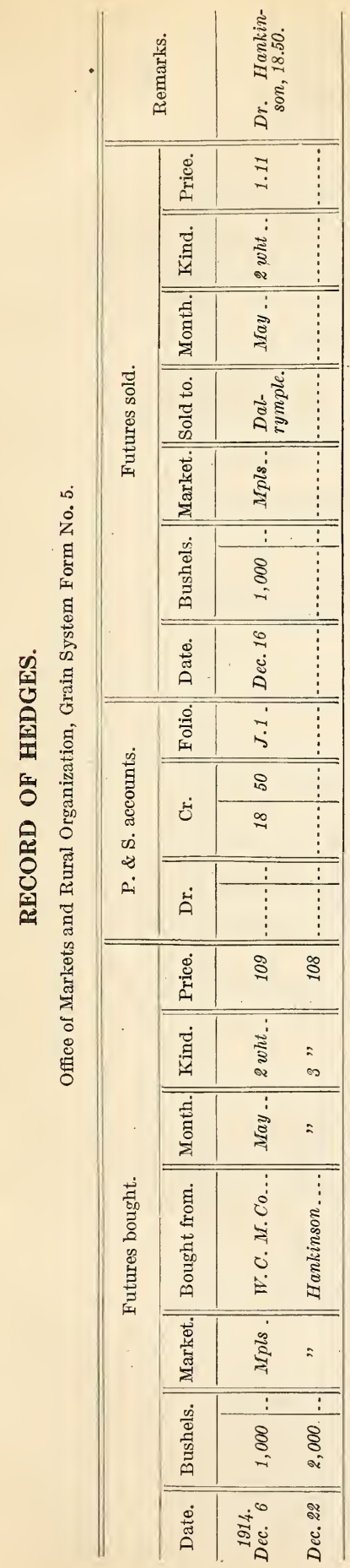

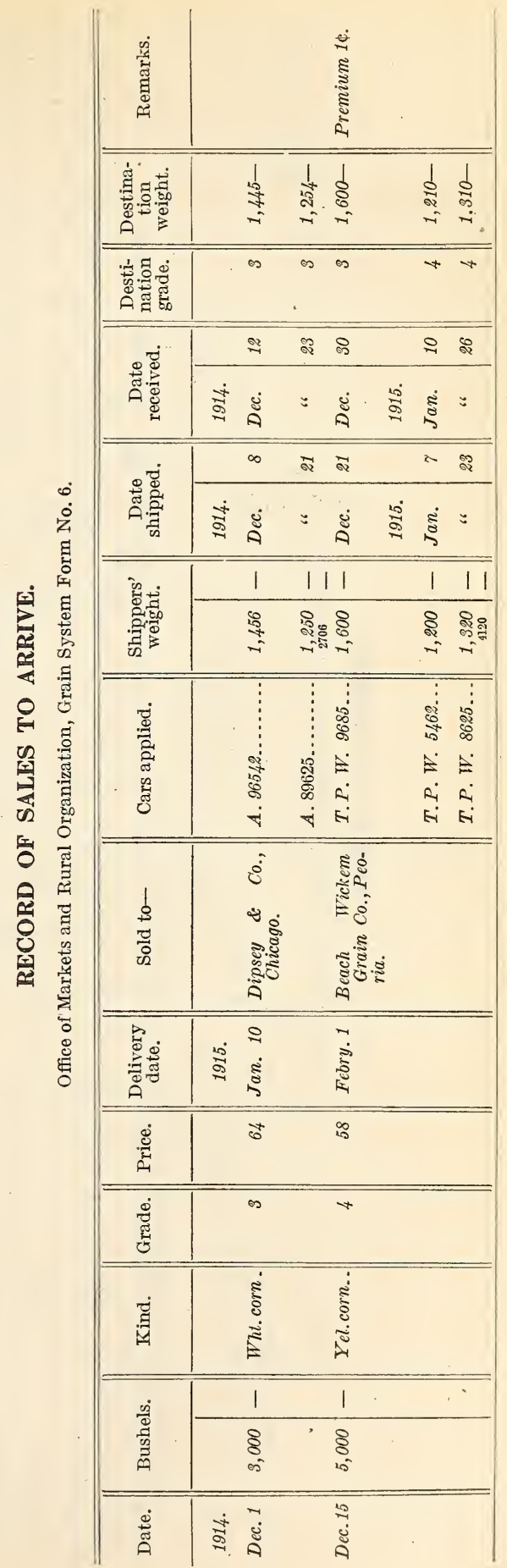


BULletin 236, U. S. DepartMent of Agriculture.

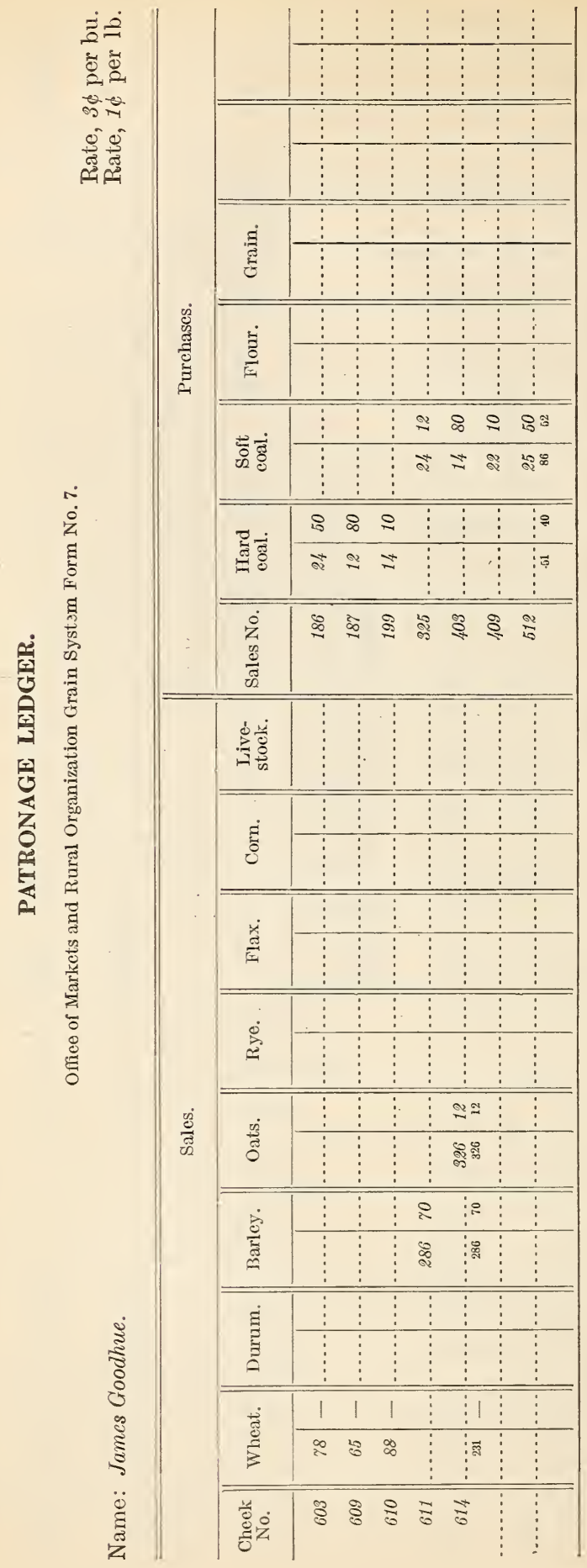


SYSTEM OF ACCOUNTS FOR FARMERS' COOPERATIVE ELEVATORS. 23

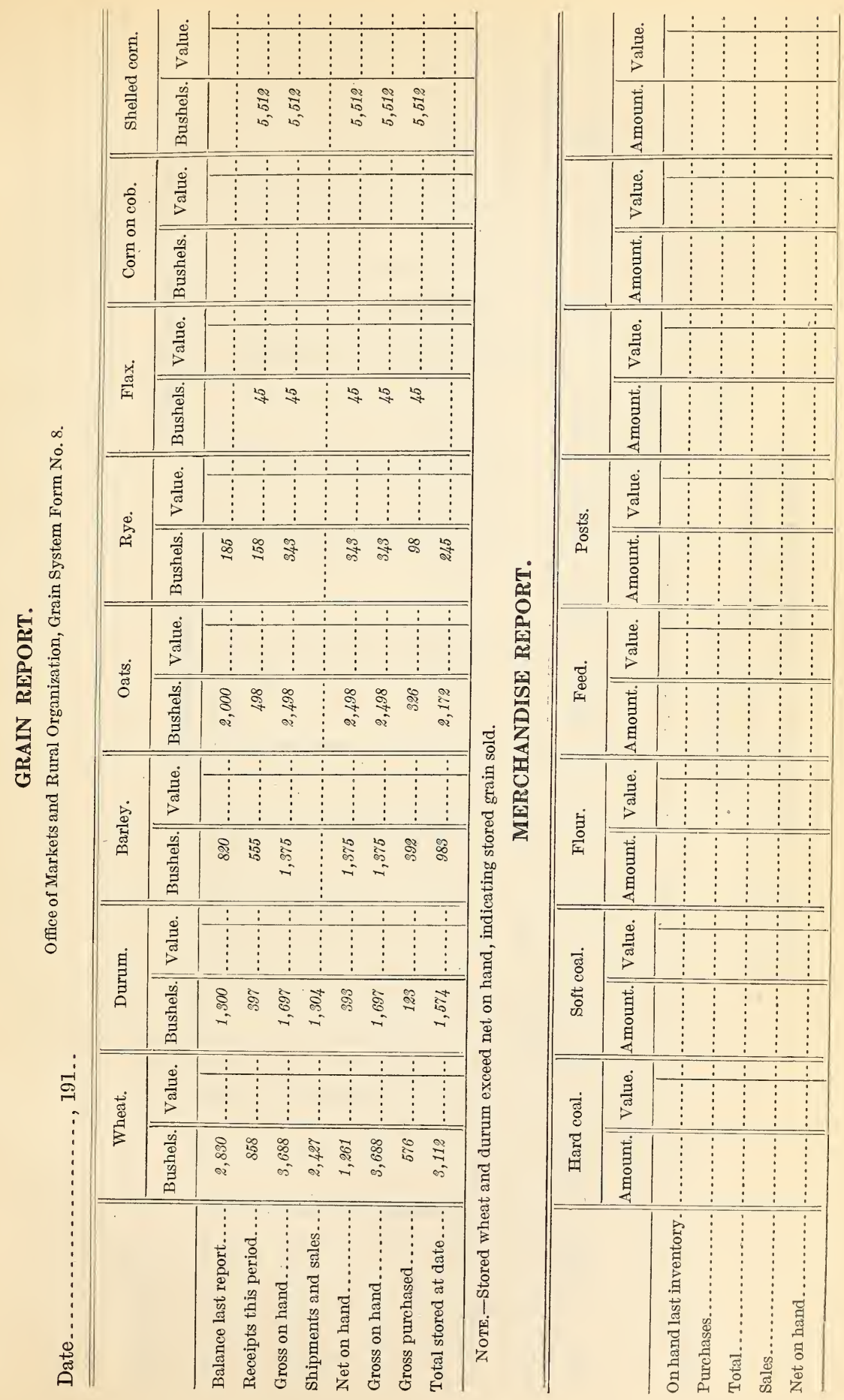


BULLETIN 236, U. S. DEPARTMENT OF AGRICULTURE.

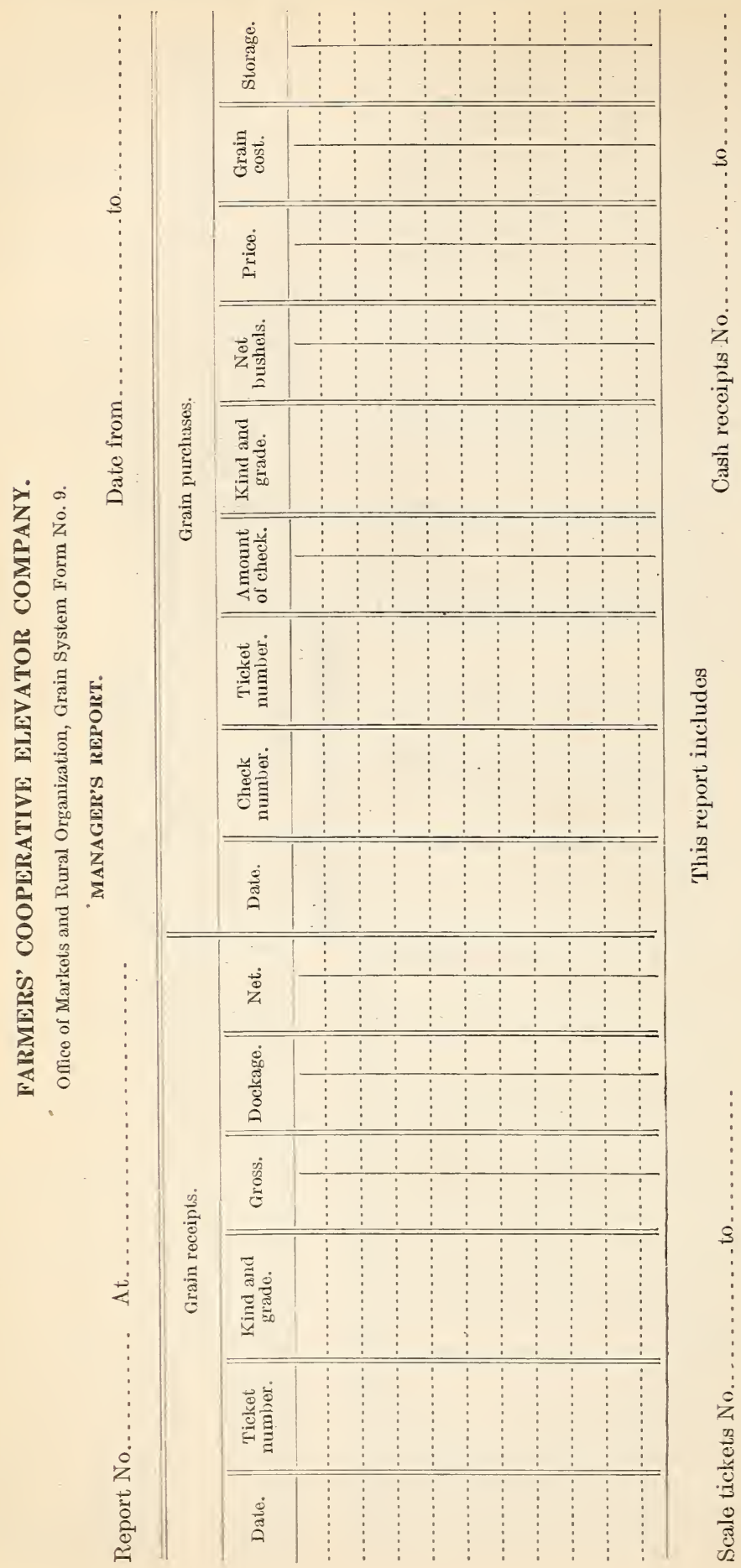


SYSTEM OF ACCOUNTS FOR FARMERS' COOPERATIVE ELEVATORS, 25

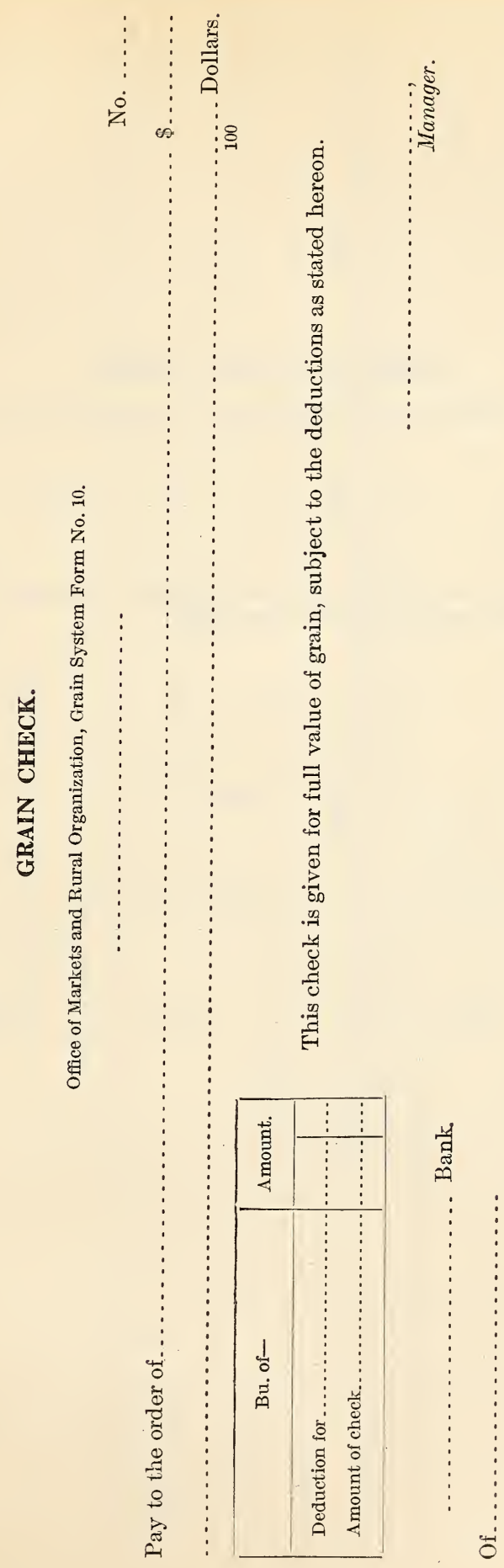




\section{WAREHOUSE SCALE TICKET.}

Office of Markets and Rural Organization, Grain System Form No. 11.

No.

\section{Co.}

\section{At}

This ticket is not a storage ticket and is not negotiable. Is must be exchanged on day of issue for a lawful storage ticket or cash check.

Owner

Driver.

On

Off.

Load of

Grade

Dockage Lbs.

Signed Agent.

Exchanged for Check No. Storage Ticket No

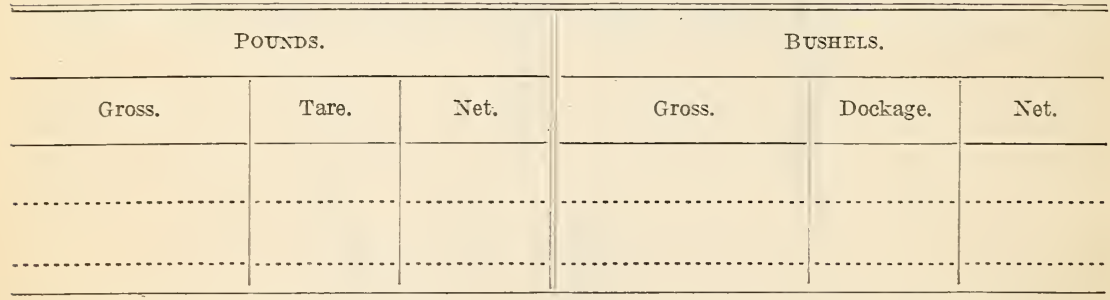


SYSTEMI OF ACCOUNTS FOR FARMERS' COOPERATIVE ELEVATORS. 27

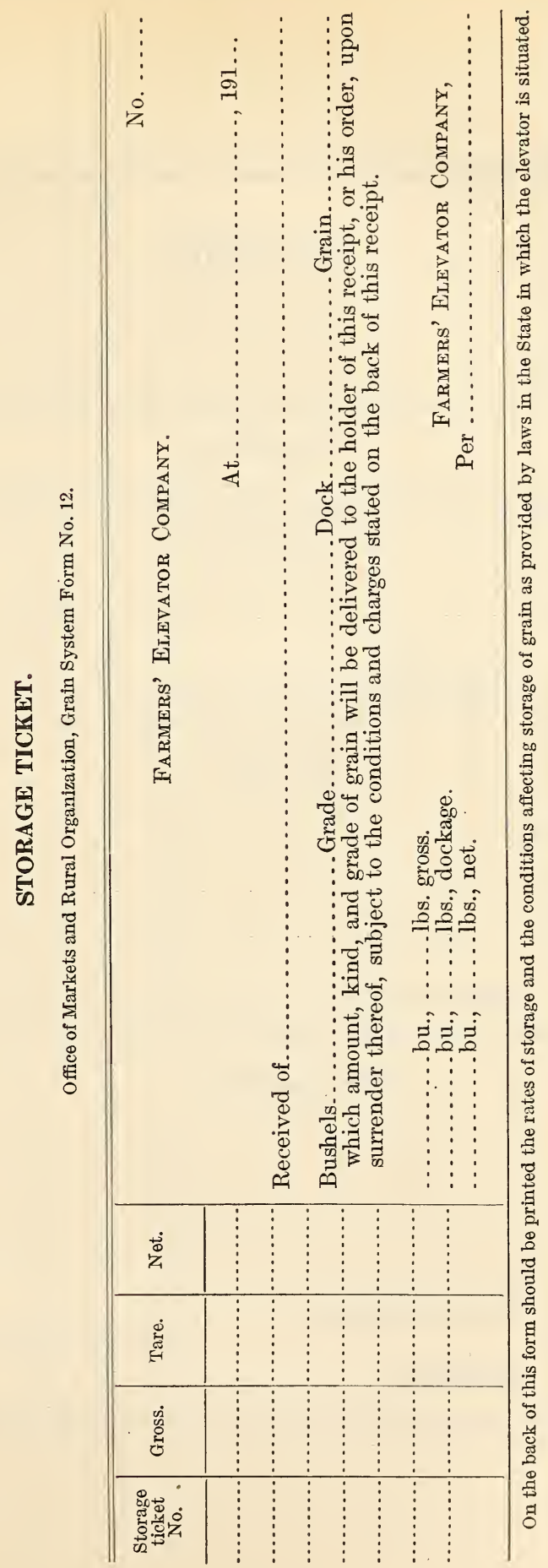


Office of Markets and Rural Organization, Grain System Form No. 13. No.

\section{SALES TICKET}

Of

At

Sold to

Date

Hard Coal.

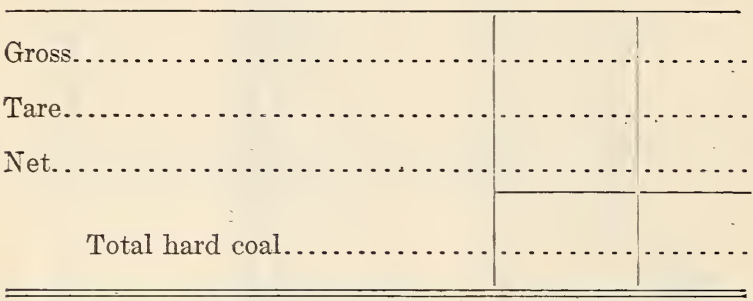

Soft Coal.

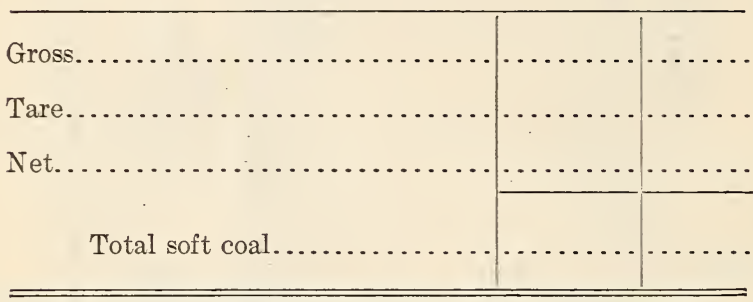

Miscellaneous.

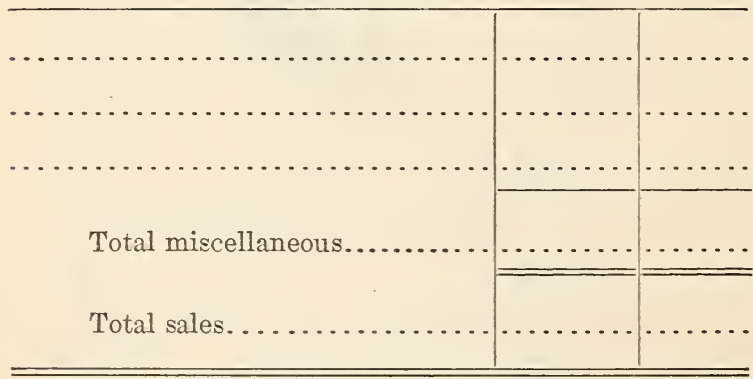


SYSTEM OF ACCOUNTS FOR FARMERS' COOPERATIVE ELEVATORS. 29

Office of Markets and Rural Organization; Grain System Form No. 14.

\section{CASH RECEIPT}

No.

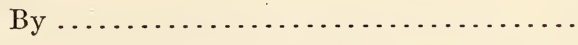

Received from

Date,

191.

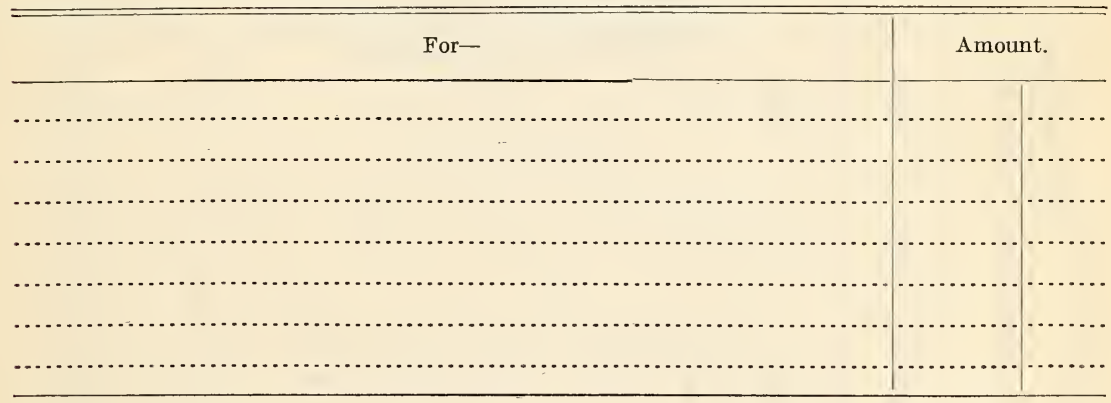


BULLETIN 236, U. S. DEPARTMENT OF AGRICULTURE.

है

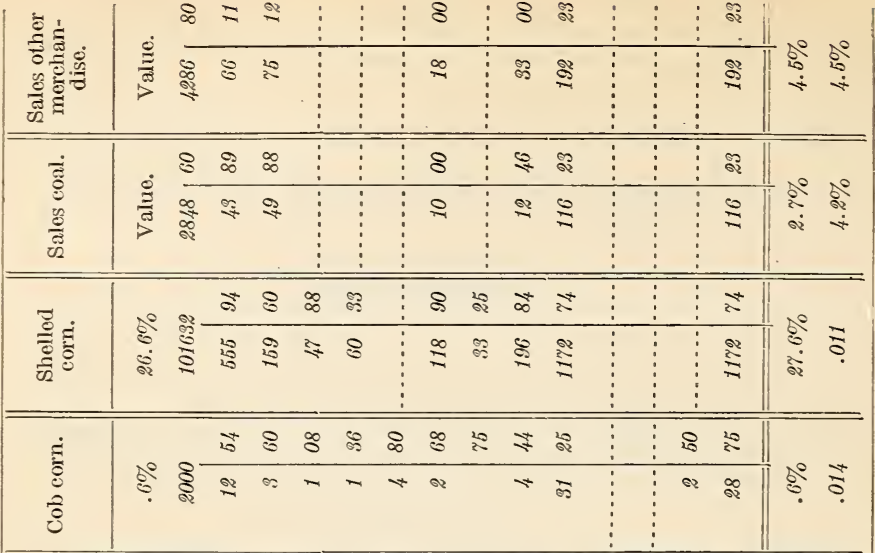

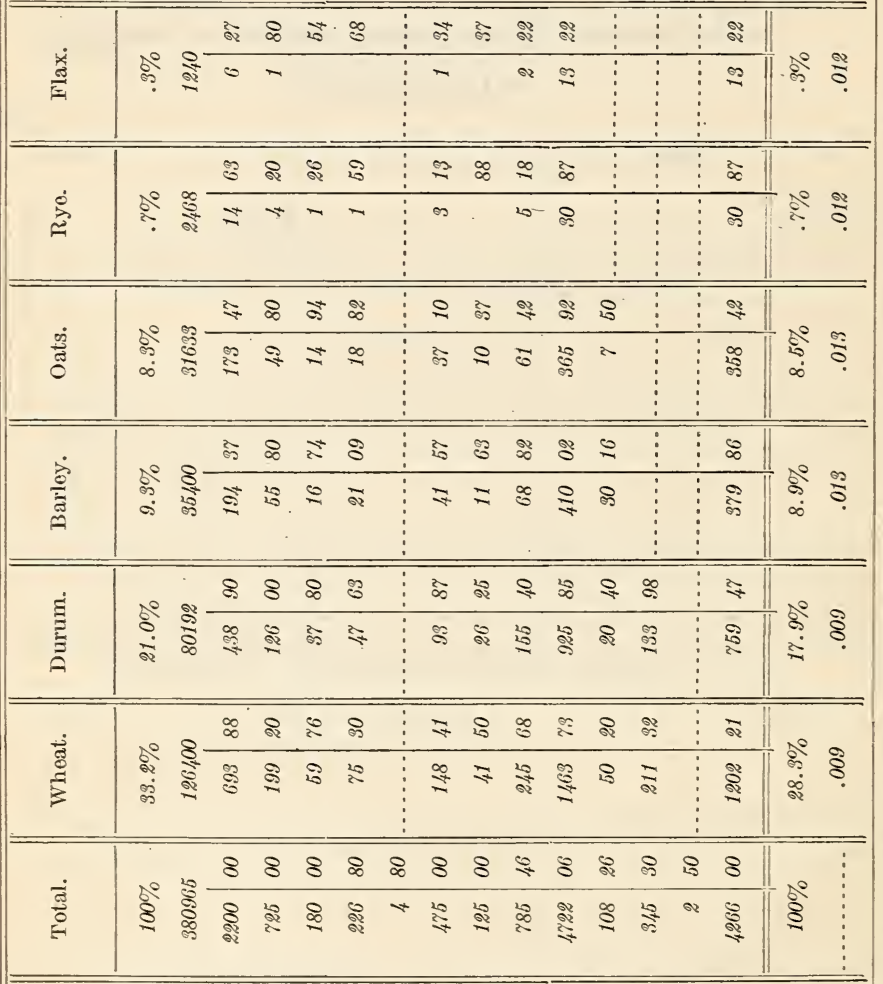

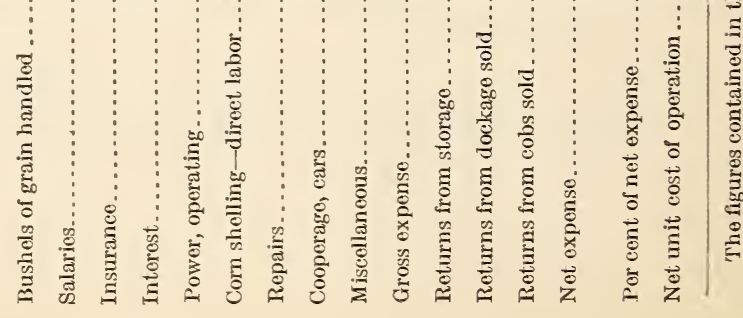


ADDITIONAL COPIES

OF THIS PUBLICATION MAY BE PROCURED FROM THE SUPERINTENDENT OF DOCUMENTS GOVERNMENT PRINTING OFFICE WASHINGTON, D. C.

AT

10 CENTS PER COPY 
